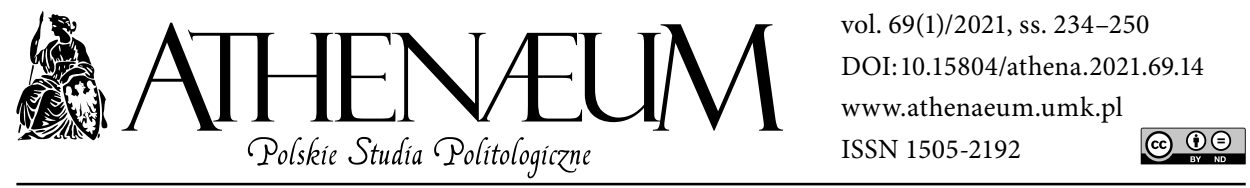

\title{
PREZYDENT W SYSTEMIE POLITYCZNYM TURCJI
}

\author{
PRESIDENT IN THE POLITICAL SYSTEM OF TURKEY
}

\author{
Dominika Liszkowska*
}

\begin{abstract}
ABSTRAKT
W niniejszym artykule przedstawiono główne cechy tureckiego modelu systemu prezydenckiego, a także historyczne uwarunkowania pozycji prezydenta w strukturze organów państwa w Turcji. Praca składa się z trzech części. $\mathrm{W}$ pierwszej z nich omówione zostały podstawy parlamentaryzmu, co jest kluczową kwestią dla ukazania kształtu tureckiego systemu przed reformą. Kolejnym zagadnieniem omawianym w tej części artykułu jest proces ewolucji prezydentury od pierwszych lat powstania Republiki do zmian wprowadzonych po wyborach prezydenckich i parlamentarnych w 2018 r. W drugiej części pracy wskazano uwarunkowania zmiany systemowej. Wreszcie w ostatniej dokonano analizy nowego systemu, określanego jako prezydencjalizm „w stylu tureckim”, i ukazano jego charakterystyczne cechy.
\end{abstract}

Słowa kłuczowe: Turcja; system prezydencki; prezydencjalizm; głowa państwa; ustrój
ABSTRACT

This article presents the main features of the Turkish presidential system and historical conditions which shaped the president's position in the power structure in Turkey. The work consists of three parts. The first part discusses the basics of Turkish parliamentarism, which is a matter crucial for understanding the organization of the Turkish system before the reform. Another issue discussed in this part is the process of evolution in the Turkish presidency from the first years of the Republic's founding to the changes introduced in 2018. The second part of this work focuses on the conditions necessary for changes in the system. Finally, the last part of the article is the analysis of the new system defined as Turkishstyle presidentialism and its distinctive features.

Keywords: Turkey; presidential system; presidency; political system

* Politechnika Koszalińska, Wydział Humanistyczny. 


\section{WPROWADZENIE}

Głowa państwa to jednoosobowy lub kolegialny organ państwa. Do jej tradycyjnych funkcji Beniamin Constant zaliczył: mianowanie oraz usuwanie piastunów władzy wykonawczej, sankcjonowanie ustaw, prawo rozwiązania zgromadzenia, prawo zwoływania sesji parlamentu, prawo mianowania sędziów, prawo łaski oraz prawo decydowania o wojnie i pokoju (Ciapała, 1996, s. 23). Głową państwa jest zwykle monarcha (w ustroju monarchicznym) lub prezydent (w ustroju republikańskim), ale może nią być także władza kolektywna (Stembrowicz, Szymczak, 1966, s. 1), czyli naczelny organ prezydialny (w systemach komunistycznych) (Bożyk, 2009, s. 161), dyktator (z tytułem lub bez) czy dowódca armii. W niektórych systemach występuje władza autokratyczna lub dyktatorska głowy państwa. W innych w rękach prezydenta skupiona jest władza wykonawcza. W jeszcze innych funkcja prezydenta sprowadza się do roli czysto symboliczno-synarchicznej (Żarnowski, 2012, ss. 93-98).

Prezydencjalizm (system/reżim prezydencki) występuje wyłącznie w państwach republikańskich (Antoszewski, Herbut, 2001, s. 320). Zgodnie z definicją Feliksa Siemieńskiego (przyjętą w ramach niniejszej analizy) jest to zespół zasad prawnoustrojowych, które w sposób szczególny określają relacje między władzą ustawodawczą (parlamentem) a władzą wykonawczą (prezydentem, będącym jednocześnie głową państwa i szefem rządu) oraz ministrami (realizatorami decyzji prezydenta), a także sądami jako organami sprawującymi wymiar sprawiedliwości i funkcję kontrolną konstytucyjności ustaw parlamentu oraz aktów prezydenta (i innych organów administracji) (Chmaj, Żmigrodzki, 2001, s. 189).

Podstawowa idea prezydencjalizmu dotyczy oparcia relacji między władzą ustawodawczą a wykonawczą na zasadzie organizacyjnej oraz funkcjonalnej separacji władzy (Antoszewski, Herbut, 2004, s. 345). W zakresie organizacyjnym oznacza to: (1) wybór prezydenta i parlamentu w drodze wyborów powszechnych, a oba organy posiadają odrębną legitymację do sprawowania władzy (osobne wybory prezydenta są wyrazem jego politycznej niezależności od parlamentu, jednocześnie służą wzmocnieniu jego pozycji wobec innych naczelnych organów) (Chmaj, Żmigrodzki, 2001, s. 189); (2) istnieje zakaz łączenia funkcji deputowanego oraz członka gabinetu; (3) prezydent powołuje ministrów, którzy stoją na czele poszczególnych resortów i którzy ponoszą przed nim odpowiedzialność polityczną.

W zakresie funkcjonalnym separacja władz oznacza, iż: (1) legislatywa posiada pełną autonomię w obrębie funkcji ustawodawczej, a prezydent do 
wykonywania prawa przyjętego przez parlament (egzekutywa nie posiada inicjatywy ustawodawczej i ma możliwość wyłącznie sugerowania parlamentowi podjęcia określonych działań); (2) prezydent nie jest odpowiedzialny politycznie przed parlamentem (choć możne być wobec niego zastosowana odpowiedzialność konstytucyjna - co dotyczy również ministrów); (3) władzy wykonawczej nie przysługuje prawo rozwiązania zgromadzenia przed upływem kadencji (Antoszewski, Herbut, 2004, s. 345).

Według Jarosława Szymanka istnieje wiele przykładów państw, które wpisują się w ramy systemu prezydenckiego, choć nie spełniają jego założeń, wychodząc w praktyce poza skalę tzw. konstytucyjnych systemów rządów właściwych dla ustroju demokratycznego. Takie państwa przyjęło się określać systemami neoprezydenckimi (neoprezydencjalizm), hiperprezydenckimi (hiperprezydencjalizm) czy superprezydenckimi. Ich wspólną cechą jest istotna ekspozycja stanowiska ustrojowego głowy państwa (prezydenta), co dla badaczy stanowi motyw porównania z klasycznym systemem prezydenckim (lub półprezydenckim) (nie uwzględniając jednocześnie założeń właściwych dla demokratycznych rozwiązań -formalnej zasady podziału władz czy materialnej zasady pluralizmu politycznego) (Szymanek, 2017, s. 104). Systemy tego rodzaju przez to, że nie spełniają cech demokratycznych, nie powinny (zdaniem niektórych badaczy) być uwzględniane jako właściwe systemy prezydenckie czy inne rozwiązania zbliżone do klasycznego modelu (nawet jeśli formalnie określone są w konstytucjach jako prezydenckie).

Jak zauważają Andrzej Antoszewski i Ryszard Herbut, w klasycznej postaci prezydencjalizm występuje w Stanach Zjednoczonych i jest to jedyny przykład tego reżimu wśród skonsolidowanych demokracji (Antoszewski, Herbut, 2001, s. 320-321). Jednak przyglądając się bliżej charakterystyce klasycznej wersji systemu prezydenckiego, nie sposób nie dostrzec, że również ona odbiega od tradycyjnych reguł podziału oraz równowagi władz, należących do współczesnych norm demokratycznych (Turek, 2014, s. 101).W literaturze podkreśla się, że konstytucyjny model prezydentury amerykańskiej „nie jest ani teoretycznie jednoznaczny, ani legislacyjnie spójny” (Osiński, 2009, s. 21-22). Szeroki zakres władzy prezydenta, który określono w Konstytucji Stanów Zjednoczonych Ameryki z 1787 r., zwiększał się ze wzrostem roli organów federalnych. Natomiast w momencie wyłaniania się nowych zadań, nieprzewidzianych przez twórców konstytucji, prezydenci podejmowali je jako zadania własnego urzędu i podległych organów federalnych władz wykonawczych, zwiększając jeszcze w ten sposób rzeczywisty zakres swojej władzy. 
Z kolei określany mianem superprezydencjalizmu (Bryc, 2009, s. 23) przypadek Rosji z prawno-formalnego punktu widzenia jest najbardziej podobny do rozwiązań ustrojowych V Republiki Francuskiej, której system określany jest jako semiprezydencki (Potulski, 2005, s. 349). Inni przyjęte w Rosji rozwiązania określają z kolei jako model rządów o silnej władzy prezydenta (Bichta, Kowalska, Sokół, 2005, s. 405), co - jak podkreśla Agnieszka Bryc -związane jest przede wszystkim z filozofią władzy (głowy państwa) w Rosji (początkowo cara, a później pierwszego sekretarza), a nie z samą tradycją prezydentury (Bryc, 2009, s. 23).

Turcja posiada bogate tradycje ustrojowe sprawowania władzy (Pogłódek, Przywora, 2016, s. 341) i z uwagi na szczególne położenie geograficzne na dwóch kontynentach, jak i zróżnicowanie narodowościowe, system ustrojowy podlegał przez lata głębokim przemianom. Reformy, które miały miejsce w tym państwie, przebiegały od przekształcenia teokratycznej monarchii i państwa wielonarodowego w scentralizowaną republikę. W ostatnich latach głębokim przeobrażeniom poddany został także system rządów i struktura oraz funkcje najważniejszych organów państwa. W niniejszym artykule autorka postara się przedstawić główne cechy tureckiego modelu systemu prezydenckiego oraz historyczne uwarunkowania pozycji prezydenta w strukturze władzy w Turcji.

(1) Hipoteza badawcza stanowi, że w przypadku zmian, które zaszły w obrębie tureckiego systemu politycznego, mamy do czynienia z transformacją struktury systemu rząadów, która dokonała się na skutek reformy zapisów Ustawy Zasadniczej z 1982 r., a następnie - w wyniku wyborów parlamentarnych i prezydenckich z 2018 r. - wprowadzona została do praktyki politycznej.

(2) Hipoteza badawcza stanowi, że system wprowadzony w Turcji nie spełnia założeń klasycznego modelu prezydencjalizmu.

Podjęty w artykule problem badawczy (prawdopodobnie z uwagi na jego aktualność) nie jest szeroko podejmowany przez polskich autorów. Większość prac przedstawia system turecki jeszcze przed dokonanymi zmianami. W tym miejscu wymienić należy prace Adama Szymańskiego (Prezydent w systemie politycznym Republiki Turcji: na tle aktualnej debaty ustrojowej - 2008, System Konstytucyjny Turcji - 2006), Karola Bieńka (Ewolucja pozycji ustrojowej władzy wykonawczej w Republice Turcji - 2016), Andrzeja Pogłódka i Bogusława Przywory (Zasady podziału władzy w Turcji - 2016), które poruszają zagadnienia związane z podziałem władzy w Turcji i pozycją ustrojową władzy wykonawczej. Istotna z punktu widzenia określenia pozycji parlamentu w tureckim systemie jest praca autorstwa Grzegorza Kryszenia z 2019 r. (System rzadów zgromadzenia 
w konstytucji Turcji z 1921 r.). Z kolei znaczenie liderów partyjnych w systemie tureckim przedstawia Jakub Wódka w rozdziale (De)europeizacja tureckich partii politycznych: aspekty instytucjonalne i transnarodowe - 2015. Ważne miejsce $\mathrm{w}$ przedmiocie poruszanego problemu badawczego stanowią analizy PISM, m.in. Karola Wasilewskiego: Turcja na drodze do systemu prezydenckiego - 2017. Uzupełnienie wiedzy w obrębie poruszanego zagadnienia stanowią prace tureckich badaczy.

Najważniejszym źródłem jest jednak Konstytucji Republiki Tureckiej z 1982 r. ze zmianami. Zastosowaną $\mathrm{w}$ pracy metodą badawczą jest analiza systemowa. W procesie badawczym wykorzystano podejście deskryptywno-eksplanacyjne, które ma pomóc odpowiedzieć na następujące pytania: Jak kształtowała się pozycja prezydenta w systemie tureckim? Jakie zmiany zostały wprowadzone w Turcji i doprowadziły do transformacji systemu? Jakie cechy posiada turecki model prezydencjalizmu? Jakie elementy odróżniają system prezydencki Turcji od klasycznego systemu prezydenckiego?

\section{KORZENIE PARLAMENTARYZMU W TURCJI I EWOLUCJA PREZYDENTURY W LATACH 1923-2018}

W okresie powstawania Republiki i od czasu zapisów konstytucyjnych z 20 stycznia 1921 r. (dokumentu, który zdaniem Grzegorza Kryszenia najlepiej określa pojęcie „małej konstytucji”) wszystkie najważniejsze uprawnienia w systemie tureckim uzyskiwał parlament - Wielkie Zgromadzenie Narodowe Turcji (Türkiye Büyük Millet Meclisi - TBMM) (Yokuş, 2018, s. 9). System parlamentarny był silnie zakorzeniony w tureckiej praktyce. Już bowiem w pierwszej Konstytucji osmańskiej z 1876 r. (Kânûn-ı Esâsî) podejmowano próby implementowania jego elementów. Zgodnie z postanowieniami tego dokumentu państwo osmańskie stało się monarchią ograniczoną, utworzoną na podstawach ustroju monarchii konstytucyjnej (niemniej jednak w dalszym ciągu $\mathrm{z}$ wyraźnym elementem absolutyzmu). Chociaż rozwiązania te nie tworzyły przesłanek do ustanowienia z parlamentu wiodącego organu w systemie władzy państwowej, to „stworzyły podstawę do rozwoju instytucji parlamentarnych w Turcji” (Kryszeń, 2019, s. 75). Następnie w wyniku nowelizacji konstytucji z 21 sierpnia 1909 r. zmieniony został dotychczasowy model jedności władzy państwowej. Wtedy też władza sułtana została znacznie ograniczona na rzecz wzmocnienia pozycji ustrojowej parlamentu, przekształcając Imperium Osmańskie w monarchię, która posiadała 
cechy rządów parlamentarno-gabinetowych (wzorowaną na europejskich rozwiązaniach konstytucyjnych - przede wszystkim na Konstytucji Belgii z 1831 r.). W dalszym ciągu jednak podstawową cechą ówczesnego ustroju politycznego była zasada suwerenności monarchy.

Z kolei wspomniane już zapisy ustawy z 1921 r. skutkowały ukształtowaniem systemu rządów zgromadzenia we wzorcowej, „czystej” jego postaci - znanej z koncepcji Jana Jakuba Rousseau i historii Rewolucji Francuskiej (Kryszeń, 2019, s. 74, 78). Sformułowana w art. 1 zasada suwerenności narodu zawarta została $\mathrm{w}$ formule stanowiącej, że „suwerenność przysługuje narodowi bez jakichkolwiek warunków”, a „system rządów opiera się na zasadzie samostanowienia i rządzenia przez ludzi” (Kryszeń, 2019, s. 79).Z zasadą tą powiązana została zasada jedności władzy, skoncentrowana w jednoizbowym Wielkim Zgromadzeniu Narodowym, któremu następnie w zapisach art. 5 Konstytucji z 1924 r. przekazano uprawnienia zarówno w zakresie władzy ustawodawczej, jak i wykonawczej (Barkey et. al., 2014, s. 9).

Ustrój republikański oraz urząd prezydenta (będącego początkowo jednocześnie przewodniczącym Wielkiego Zgromadzenia Narodowego, wybieranym spośród jego członków) wprowadzono w 1923 r. (Szymański, 2008, s. 128). Zgodnie z zapisami art. 32 Konstytucji z 1924 r. prezydent dzielił z rządem władzę wykonawczą i był głową państwa. Wszystkie jego postanowienia wymagały kontrasygnaty premiera i właściwego ministra. Należy jednak zwrócić uwagę, że chociaż zakres kompetencji, które uzyskał w pierwszych latach Republiki prezydent, określić można jako ceremonialne (Barkey et. al., 2014, s. 9), to dysponował on znacznie większą władzą, ponieważ był jednocześnie liderem organizacji partyjnej mającej większość w parlamencie, który go wybierał (Bieniek, 2016, s. 399). Jak zauważają Danuta Chmielowska oraz Mikołaj Sobczak, polityczny ustrój Turcji „mimo systemu parlamentarnego i zapewnień o wprowadzaniu demokracji wzorowanej na państwach europejskich" był w rzeczywistości w pierwszych latach Republiki „dyktaturą pierwszego jej prezydenta Mustafy Kemala i utworzonej w 1922 r. Republikańskiej Partii Ludowej (Cumhuriyet Halk Fırkası)" (Chmielowska, Sobczak, 2016, s. 213).

W wyniku reform dokonanych kolejną Ustawą Zasadniczą z 1961 r. najbardziej istotną zmianą w systemie tureckim był podział funkcji władzy wykonawczej oraz ustawodawczej i przekazanie ich odrębnym organom. Władza wykonawcza (prezydent i rada ministrów) nie pochodziła już z parlamentu (Bieniek, 2016, s. 401), co określić można jako nową właściwość systemu. Prezydent posiadał szereg kompetencji o charakterze symbolicznym (otrzymał m.in. uprawnienia 
do ratyfikacji traktatów czy możliwość ułaskawienia). Nie mógł jednak ubiegać się o reelekcję i zgodnie z zapisami art. 96 Konstytucji musiał zrzec się przynależności partyjnej (Barkey et. al., 2014, ss. 10-11).

Pozycja prezydenta $\mathrm{w}$ systemie politycznym Turcji została wzmocniona w obowiązującej Konstytucji z 1982 r. W jej preambule zdefiniowana została rola zasady trójpodziału władzy i tak: „Konstytucja [...] wyraża [...] zasadę podziału władzy, która nie ustanawia hierarchii organów państwa, a odnosi się jedynie do wykonywania uprawnień i obowiązków, opartych na współdziałaniu i rozdziale funkcji [...]”. W wyniku zapisów konstytucyjnych Wielkie Zgromadzenie Narodowe kolejny raz uzyskało rozległe kompetencje stanowiące o jego silnej pozycji ustrojowej i, jak zauważa Adam Szymański, to uprawnienia tego organu przesądzały o uznaniu tureckiego systemu rządów za parlamentarno-gabinetowy (Szymański, 2006, s. 44).

Nowa Konstytucja co do zasady przekształciła też symboliczny urząd prezydenta w znaczącą instytucję z ważnymi funkcjami oraz możliwością aktywnego udziału w podejmowaniu decyzji w państwie. Turcja (obok Grecji i Włoch) zaliczana była do republikańskich systemów politycznych, w których głowa państwa w sposób aktywny starała się uczestniczyć w polityce państwa (Knopek, 2016, s. 43). Zgodnie z zapisami konstytucji prezydent obok rady ministrów był organem władzy wykonawczej i odgrywał kluczową rolę w systemie. W celu realizacji spoczywających na nim obowiązków został wyposażony w szereg uprawnień zawartych w art. 104. Według Adama Szymańskiego „z przepisów konstytucji dotyczących bezpośrednio Prezydenta Republiki trudno [było jednak] odczytać właściwą pozycję ustrojową tego organu”. Wprawdzie lista kompetencji została wyraźnie przedstawiona, to zapisy nie ukazały sposobu korzystania z przekazanych uprawnień oraz nie wskazały istniejących ograniczeń (Szymański, 2006, s. 53). Biorąc pod uwagę wyłącznie zawarte w art. 104 ust.1 prerogatywy prezydenta, odnieść można wrażenie, iż jego pozycja była podobna do prezydentury francuskiej (choć z przepisów traktujących o innych organach władzy, dotyczących także funkcji prezydenta, można było wysnuć inne wnioski). Ergun Özbudun zauważa, iż wzmocniona zapisami Konstytucji z 1982 r. pozycja prezydenta nie ukierunkowała tureckiego systemu rządów w stronę systemu prezydenckiego. Odnosząc się do jej zapisów, nie było też podstaw do mówienia o systemie semiprezydenckim, bowiem prezydentura ta pomimo pewnych korekt była właściwa dla systemu parlamentarnego (jednak odeszła od modelu prezydentury wyłącznie symbolicznej i ceremonialnej) i silnie wpisała się w ten system, czego wyrazem był tryb wyboru prezydenta przez parlament (historyczne 
rozwiązania dla parlamentarno-gabinetowego systemu rządów) (Szymański, 2008, s. 130). Jednocześnie jednak w systemie, w którym prezydent wybierany jest przez parlament, oczekuje się jego symbolicznej roli, ograniczonej legitymacji politycznej oraz neutralności w zakresie polityki partyjnej (Elman, 2014, ss. 1-2), a to w przypadku Turcji realizowane było w ograniczonym zakresie.

Pierwsza bardzo istotna zmiana w obrębie tureckiej prezydentury miała miejsce w maju 2007 r., kiedy rząd Partii Sprawiedliwości i Rozwoju (AKP) przedstawił projekt zawierający propozycje zmian w Konstytucji z 1982 r. Zmiany zostały następnie przyjęte przez obywateli w drodze referendum. Wyniki głosowania i aprobata społeczeństwa dla proponowanych przez AKP reform (za zmianami opowiedziało się 68,95\% uprawnionych do głosowania) (Bieniek, 2013, s. 191) wpłynęły w istotny sposób na przeobrażenia w obrębie struktury systemu politycznego Turcji. W ramach reformy dokonano bowiem zmiany trybu wyboru głowy państwa z pośredniej dokonywanej przez parlament, na elekcję w wyniku głosowania powszechnego. Skrócono też kadencję prezydenta z siedmiu do pięciu lat, a wybranej przez obywateli głowie państwa umożliwiono reelekcję (Kaya, 2011, s. 3).

\section{UWARUNKOWANIA ZMIANY SYSTEMOWEJ}

Rozwiązania przyjęte w Ustawie Zasadniczej z 1982 r. obowiązywały w rzeczywistości do 2014 r., kiedy po raz pierwszy prezydent został wybrany w sposób bezpośredni w wyborach powszechnych. W trakcie kampanii prezydenckiej przed tymi wyborami przywódca rządzącej AKP Recep Tayyip Erdoğan dał jasno do zrozumienia, że jeśli zostanie wybrany przez społeczeństwo, nie będzie sprawował funkcji wyłącznie symbolicznej i ceremonialnej (jak to ujął nie zostanie „prezydentem doniczką"1), ale będzie prezydentem aktywnym, który wykorzysta swoje konstytucyjne uprawnienia w sposób maksymalny (Özbudun, 2014, s. 3).

Propozycja zmiany systemu Turcji na prezydencki zaczęła pojawiać się w debacie rządu AKP szczególnie często po zwycięstwie wyborczym w 2011 r. W propozycjach na temat systemu rządów wyłaniała się koncepcja stworzenia modelu zbliżonego do amerykańskiego (Çolak, Şener, Bilgili, 2017, s. 119). Propozycja ta nie była rewolucyjna w przypadku tego państwa. Wcześniej

\footnotetext{
1 “a flower-pot president".
} 
bowiem podobne inicjatywy kierowano w latach prezydentury Turguta Özala (1989-1993) i Süleymana Demirela (1993-2000).

Przedstawiciele AKP coraz wyraźniej podkreślali, że po uzyskaniu niezbędnej konstytucyjnej większości w kolejnych wyborach parlamentarnych dokonają zmiany systemu na prezydencki lub semiprezydencki, a za argument do wprowadzenia tej zmiany uznawali m.in. to, że silna władza wykonawcza jest niezbędnym czynnikiem dla szybkiego podejmowania decyzji i kroków w procesie demokratycznego oraz gospodarczego rozwoju państwa. Uznano też, że proponowany system prezydencki będzie bardziej zgodny z turecką kulturą polityczną aniżeli system parlamentarny, bowiem już w pierwszych latach po powstaniu Republiki występowała de facto jego forma, kiedy na czele partii politycznej stał prezydent sprawujący swój urząd.

Kwestia wprowadzenia systemu prezydenckiego pojawiała się w debacie politycznej w Turcji na przestrzeni kolejnych lat. Stanowisko byłych prezydentów, optujących za systemem prezydenckim, również miało potwierdzić konieczność jego wprowadzenia. Podkreślano, że system prezydencki zapobiega tworzeniu koalicji, które w przeszłości szkodziły Turcji zarówno pod względem stabilności demokratycznej, jak i ekonomicznej. Zmiany miały położyć kres wielu poważnym kryzysom rządowym oraz doświadczeniom tureckiego życia politycznego i zapewnić bardziej polityczny charakter ram tworzenia nowych rządów (Serdar Gülener i Nebi Miş twierdzą wręcz, że zmiana systemu na prezydencki miała doprowadzić do końca „kryzysu tureckiego systemu parlamentarnego nad którym debatowano ostatnie czterdzieści lat") (Gülener, Miş, 2017, s. 9). Nowy system miał zapewnić też nienaruszalność zasady trójpodziału władzy, bowiem zgodnie z założeniami parlament $\mathrm{w}$ dalszym ciągu posiadałby silną i niezależną pozycję w systemie politycznym. Zrównoważenie systemu za pośrednictwem jego zmiany miało stanowić też silniejszą podstawę dla gospodarki. Ponadto reforma miała doprowadzić do wyeliminowania zakorzenionych od lat w Turcji problemów wewnętrznych i stworzyć m.in. silniejszą barierę przeciwko różnego rodzaju zamachom.

Propozycje AKP wywoływały jednak liczne kontrowersje. Były one w przeważającej części efektem zapowiedzi przedstawicieli obozu rządzącego, definiujących nowy system rządów jako system prezydencki „w tureckim stylu” (Wasilewski, 2017b, s. 10). Takie określenie wywołało krytykę ze strony opozycji i opinii publicznej, które obawiały się, iż przygotowywane zmiany mogą wpłynąć negatywnie na zachowanie trójpodziału władzy i stanowić koniec demokracji. 
W trakcie przygotowywania reformy partia rządząca nie dysponowała odpowiednią większością parlamentarną, która umożliwiałaby jej samodzielną zmianę konstytucji. W październiku 2016 r. wsparcie dla propozycji ogłosił jednak lider Partii Ruchu Narodowego (MHP) Devlet Bahçeli. Rozmowy rozpoczęte w wyniku uzgodnień międzypartyjnych skutkowały wypracowaniem w grudniu 2016 r. wspólnego projektu reformy zapisów konstytucyjnych (Wasilewski, 2017a, s. 1). 21 stycznia $2017 \mathrm{r}$. turecki parlament przyjął pakiet poprawek rozszerzających uprawnienia głowy państwa, które następnie 16 kwietnia społeczeństwo zatwierdziło w ogólnonarodowym referendum.

Należy podkreślić, iż sama kampania referendalna i głosowanie nad zmianami odbyły się w bardzo kontrowersyjnych okolicznościach i mało demokratycznych (Makovsky, 2017), czyli w czasie trwania stanu nadzwyczajnego wprowadzonego w wyniku puczu z lipca 2016 r. oraz wewnętrznej destabilizacji spowodowanej licznymi atakami terrorystycznymi (Chudziak, 2017). Za systemem prezydenckim i zmianami opowiedziało się jednak 51,4\% Turków biorących udział w referendum (Wasilewski, 2017c), co pozwoliło na rozpoczęcie okresu przejściowego, który miał zapewnić przygotowanie dla zmiany systemu pod względem prawnym i instytucjonalnym.

\section{TRANSFORMACJA STRUKTURY SYSTEMU RZĄDÓW - SYSTEM PREZYDENCKI „W STYLU TURECKIM"}

Zaproponowany w referendum pakiet zmian zakładał 18 wskazań, zmieniających lub uchylających ponad 65 artykułów (spośród 177) Konstytucji z 1982 r. Jednym $\mathrm{z}$ novum zastosowanym $\mathrm{w}$ tureckim systemie jest zniesienie urzędu premiera. Będący głową państwa prezydent przejął wszystkie obowiązki oraz prerogatywy szefa gabinetu i stanął na czele rządu. Zgodnie z zapisami rozdziału II tureckiej Ustawy Zasadniczej władzę wykonawczą w Turcji sprawuje prezydent (art. 104), zatem zastosowany model egzekutowy ma charakter monokratyczny (jednolity) i zamknięty (Żmigrodzki, Dziemidok-Olszewska, 2007, s. 18), gdzie cała władza wykonawcza skupiona jest w jednym organie państwowym, który za nią odpowiada (Knopek, 2016, s. 40) (podobna struktura egzekutywy występuje m.in. w Stanach Zjednoczonych, Indonezji czy na Cyprze). Zmianę tę można uznać za najistotniejszą z punktu widzenia struktury systemu, bowiem wypływa ona w zasadzie na wszystkie pozostałe jego elementy. Władza wykonawcza może być $\mathrm{w}$ dowolny sposób kształtowana przez prezydenta, a wszystkie jej czynniki 
składowe bez względu na stopień ustawowej samodzielności działają w obrębie władzy prezydenta (będącego jej wyłącznym i całkowitym szefem) (Sarnecki, 2013, s. 102). Może on powoływać i odwoływać wszystkich wyższych urzędników zgodnie z własnym wyborem bez kontroli i konieczności uzyskania zgody parlamentu lub innego organu (jak ma to miejsce np. w obrębie nominacji prezydenta USA, które muszą być następnie zatwierdzone przez Senat).

Nowy system turecki jest tym samym wyrazem skoncentrowania politycznej potęgi prezydentury, którą można określić mianem „imperatorskiej” czy „cezarystycznej", odbiegającej w istotnym stopniu od tradycyjnych reguł podziału oraz równowagi władz (Turek, 2014, s. 101). Ponadto za sprawą wprowadzonych zmian Turcja znalazła się wśród nielicznych krajów na świecie, w których więzi wyborcze między egzekutywą a władzą ustawodawczą są bardzo głębokie. Cechą charakterystyczną systemu jest bowiem przeprowadzenie równoległych wyborów prezydenckich i parlamentarnych. W przypadku Turcji monokratyczna władza wykonawcza oraz parlament (władza ustawodawcza), poza tym, że są wybierane tego samego dnia, mogą doprowadzić do przedterminowych elekcji. Prezydent ma jednak przewagę w tym zakresie, bowiem w każdej chwili może rozpisać nowe wybory, natomiast parlament potrzebuje do tego większości 3/5 ogólnej liczby członków (art. 116). Jest to podstawowy element, który odróżnia klasyczny system prezydencki od modelu tureckiego (ten pierwszy nie zapewnia bowiem prezydentowi możliwości skrócenia kadencji zgromadzenia) (Żmigrodzki, Dziemidok-Olszewska, 2007, s. 18).

Ponadto prezydent zachowuje, ale też znacznie powiększa uprawnienia merytoryczne, które pierwotnie przyznawała mu obowiązująca konstytucja. W ramach jej zapisów uzyskuje on m.in. kompetencje w zakresie określenia i podejmowania niezbędnych środków celem zapewnienia polityki bezpieczeństwa narodowego, przedstawia propozycję ustawy budżetowej parlamentowi (art. 161), może też powołać wiceprezydentów - nowy urząd powstały w wyniku reform (co ciekawe konstytucja nie wskazuje liczby wiceprezydentów, którzy mogą jednocześnie sprawować tę funkcję) (Marszałek-Kawa, Burak, 2018, s. 100). Ograniczenie kompetencji prezydenta w obrębie zapisów konstytucyjnych odnaleźć można w zasadzie tylko w przypadku ustawy budżetowej, która wymaga zatwierdzenia przez parlament.

Prezydent za sprawą wprowadzonych zmian uzyskał też możliwość wydawania dekretów (cumhurbaşkanının kararname) z mocą prawną (ograniczenie w tej materii stanowi m.in. zapis, iż nie mogą one regulować podstawowych praw i obowiązków jednostki zapewnionych w konstytucji czy materii zastrze- 
żonych dla ustaw - art. 104). Możliwość wydawania dekretów stanowi zatem znaczące, nowe uprawnienie władzy wykonawczej poza tymi, które są nieodłącznie związane $\mathrm{z}$ prezydenturą lub funkcją premiera $\mathrm{w}$ innych systemach. Oczekiwano, że pakiet zmian będzie obejmował w zasadzie nieograniczoną władzę decyzyjną prezydenta. W rzeczywistości jednak w zakresie stanowienia prawa władza prezydenta określona w konstytucji jest znaczna, ale ograniczona. W przypadku uchwalenia przez Wielkie Zgromadzenie Narodowe ustaw, których postanowienia dotyczą tej samej materii co dekret prezydenta, ten drugi ulega unieważnieniu. Tym samym pomimo wzmocnienia pozycji egzekutywy w tym zakresie, uchwalane przez legislatywę prawodawstwo wciąż ma pierwszeństwo (Makovsky, 2017). Prezydent zyskał też szerokie możliwości wydawania rozporządzeń $\mathrm{z}$ mocą prawa w sprawach społecznych, gospodarczych, a nawet politycznych, jednak tylko w sytuacji braku działań parlamentu.

Głowa państwa w Turcji jest wybierana bezpośrednio przez naród spośród obywateli, którzy ukończyli czterdzieści lat i posiadają wyższe wykształcenie oraz bierne prawo wyborcze do parlamentu (art. 101). Porównując pozycję prezydenta na podstawie sposobu jego wyboru, należy uznać, iż jego legitymacja jest szersza niż np. prezydenta USA, który wybierany jest w sposób pośredni (Żmigrodzki, Dziemidok-Olszewska, 2007, s. 33). Kadencja prezydenta Turcji trwa 5 lat i ta sama osoba może być wybrana na urząd najwyżej dwukrotnie. Zapisy konstytucji wskazują jednak wyjątek sprawowania urzędu przez tę samą osobę po raz trzeci, co może nastąpić w wyniku decyzji (zwiększonego do 600 członków) Wielkiego Zgromadzenia Narodowego o rozpisaniu przedterminowych wyborów parlamentarnych. Stanowi o tym art. 116: „W przypadku postanowienia przez Zgromadzenie o ponownym przeprowadzeniu wyborów, Prezydent Republiki sprawujący urząd drugą kadencję, może kandydować w wyborach ponownie”.

Konstytucja Turcji uznaje też wyjątek w kwestii przeprowadzenia jednoczesnej elekcji prezydenta i parlamentu - i tak w sytuacji opróżnienia urzędu prezydenta, gdy do wyborów powszechnych pozostał okres dłuższy niż jeden rok, wybiera się nowego prezydenta, który pełni obowiązki do czasu przypadającego na kolejne wybory parlamentarne (i w tej sytuacji okres sprawowania urzędu nie będzie zaliczony jako kadencja prezydenta - art. 106). Z kolei gdy do przeprowadzenia kolejnych wyborów powszechnych pozostał okres do jednego roku -wraz z wyborami prezydenckimi przeprowadzone zostaną wybory do zgromadzenia.

Kolejną istotną zmianą jest umożliwienie prezydentowi członkostwa w partii politycznej i bycia jej liderem (co jak zauważa Mateusz Chudziak relatywnie wpływa na zmniejszenie roli samej partii, bowiem będzie ona kontrolowana 
przez prezydenta osobiście, stanowiąc jedynie kadrowe zaplecze i instytucjonalny łącznik pomiędzy rządem a społeczeństwem) (Chudziak, 2018). Biorąc pod uwagę funkcjonowanie systemu, gdy partia prezydenta stanowi większość parlamentarną, kontrola jego władzy praktycznie nie istnieje. W odwrotnej sytuacji, gdyby partia prezydenta nie miała większości, zapewne konieczna byłaby współpraca wszystkich ugrupowań zasiadających w parlamencie i najważniejszych instytucji państwowych, celem uniknięcia chaosu oraz nieporozumień na poziomie wszystkich elementów władzy - co w praktyce może doprowadzić do sytuacji, której nowy system miał zapobiec (Makovsky, 2017).

Przeniesienie pozycji partyjnej lidera na poziom państwa doprowadziło zatem do powstania zjawiska tzw. prezydencji partyjnej czy prezydentury partyjnej. Jednak zmiana ta jest w przypadku Turcji szczególnie istotna. Jak zwraca bowiem uwagę Jakub Wódka: „w warunkach tureckich w stopniu większym niż w państwach o ugruntowanej demokracji swoje piętno na polityce wewnętrznej i zagranicznej [...] odciskają charyzmatyczni liderzy, stojący na czele ugrupowań politycznych" (Wódka, 2015, s. 144). Specyfiką tureckiego społeczeństwa jest bowiem kult liderów oraz patriarchalna kultura, które faworyzują silnych, charyzmatycznych przywódców i sprzyjają akceptacji autorytarnych zachowań władzy (kosztem polityków koncyliacyjnych) (Matusiak, 2015, s. 18). System Turcji można zatem określić jako „polityczny feudalizm”. Autorzy zajmujący się tematyką partii politycznych mówią wręcz o zjawisku „oligarchii liderów partyjnych”, ,wewnątrzpartyjnej autokracji”,,tendencjach oligarchicznych”, ,wysoce zdyscyplinowanym przywództwie partyjnym” czy „nadmiernie scentralizowanych strukturach”. Taka sytuacja w literaturze określana jest „jako personalizacja polityki, w której pierwszoplanową rolę odgrywa silny przywódca - przewodniczący partii, „indywidualny aktor polityczny [co odbywa się jednak] kosztem partii i kolektywnej tożsamości ugrupowania” (Wódka, 2015, s. 144).

Jedną $\mathrm{z}$ większych kontrowersji w zakresie wprowadzonych $\mathrm{w}$ tureckim systemie zmian stanowi zwiększenie kompetencji prezydenta $\mathrm{w}$ obrębie wymiaru sprawiedliwości. Pakiet poprawek wzmocnił kontrolę prezydenta nad sądownictwem, a prezydent uzyskał znaczący zakres uprawnień i tym samym wpływ na dwa ważne organy sądowe: Radę Sędziów i Prokuratorów (Hâkimler ve Savcılar Kurulu - HSK - która decyduje o powołaniu sędziów i prokuratorów, mianowaniu, przenoszeniu na inne stanowiska, delegowaniu, awansach, a także wymierzaniu kar dyscyplinarnych i usuwaniu ze służby - art. 159) oraz Trybunał Konstytucyjny (czyli sąd badający konstytucyjność ustaw oraz rozpatrujący domniemane przestępstwa popełnione przez najwyższych urzędników 
- działając jako Trybunał Stanu - art. 148). Nominacje prezydenta w obrębie tych organów władzy sądowniczej nie podlegają rewizji przez parlament, ani żaden inny organ. Zgodnie z przyjętymi zmianami prezydent (4) i Wielkie Zgromadzenie (7) wyznaczają 11 członków z 13 członków HSK, dwaj pozostali to Minister Sprawiedliwości (będący przewodniczącym Rady) oraz Podsekretarz Stanu w Ministerstwie Sprawiedliwości (art. 159). Gdyby partia prezydenta miała większość w parlamencie, w rzeczywistości mógłby on mianować wszystkich 13 członków, a to w praktyce oznacza kontrolę głowy państwa nad sądownictwem (Chudziak, 2017). Główna zmiana w zakresie działalności Trybunału Konstytucyjnego polega $\mathrm{z}$ kolei na zlikwidowaniu dwóch miejsc zarezerwowanych dla sędziów wojskowych. Trybunał składa się z 15 sędziów cywilnych, i tak jak wcześniej trzech z nich zostaje mianowanych przez parlament, a pozostałych 12 przez prezydenta (art. 146).

\section{PODSUMOWANIE}

W 2018 r. parlamentarno-gabinetowy system Turcji został przekształcony w system prezydencki. Bez wątpienia w przypadku zmian, które zaszły w obrębie tureckiego systemu politycznego, mamy do czynienia z transformacją struktury systemu rządów, o czym świadczy chociażby monokratyczna egzekutywa skupiona od teraz w rękach głowy państwa. Wprowadzone zmiany pozwalają wyłonić zarówno prezydenta - dysponenta władzy wykonawczej, jak i Wielkie Zgromadzenie Narodowe w drodze wyborów powszechnych, przeprowadzonych tego samego dnia. Bezpośrednia elekcja prezydenta jest wyrazem politycznej niezależności od parlamentu i służy wzmocnieniu jego pozycji wobec innych naczelnych organów. W tureckim systemie (podobnie jak w klasycznym modelu prezydencjalizmu) istnieje zakaz łączenia funkcji deputowanego oraz wiceprezydenta lub ministra (art. 106), a ministrowie, którzy stoją na czele poszczególnych resortów oraz wiceprezydenci ponoszą odpowiedzialność polityczną przed prezydentem. Wielkie Zgromadzenie Narodowe posiada pełną autonomię w obrębie funkcji ustawodawczej, z kolei prezydent w obrębie egzekutywy. Inicjatywę ustawodawczą posiadają wyłącznie deputowani (art. 88), a prezydent może jedynie zwracać ustawy do parlamentu w celu ich ponownego rozpatrzenia. Głowa państwa nie jest też odpowiedzialna politycznie przed zgromadzeniem. Może być wobec niej wszczęte śledztwo parlamentarne w przypadku podejrzenia o popełnienie przestępstwa. 
W tureckim systemie istnieje możliwość rozwiązania zgromadzenia przed upływem kadencji przez samego prezydenta, co nie jest cechą charakterystyczną klasycznego modelu systemu prezydenckiego. Zapisy Konstytucji z 1982 r. zmienione w wyniku reformy pozwalają głowie państwa rozpisać nowe wybory, prowadzące zarówno do nowej elekcji parlamentarnej, jak i prezydenckiej. Turecki model w sensie formalno-prawnym nie może zatem zostać jednoznacznie uznany i określany jako system prezydencki. Najwłaściwszym określeniem wydaje się być w jego przypadku turecki model systemu prezydenckiego czy prezydencjalizm w stylu tureckim. W jego obrębie istnieją bowiem także unikalne rozwiązania odnoszące się do równoczesnych wyborów parlamentarnych i prezydenckich czy możliwości sprawowania dodatkowej kadencji przez prezydenta w przypadku rozpisania przedterminowych wyborów.

\section{BibLIOGRAFIA:}

Antoszewski, A., Herbut, R. (2001). Systemy polityczne wspótczesnego świata. Gdańsk: Arche.

Antoszewski, A., Herbut, R. (2004). Leksykon politologii wraz z Aneksem o: reformie samorzadowej, wyborach do sejmu, prezydenckich oraz gabinetach rządowych. Wrocław: Wydawnictwo ALTA 2.

Barkey H., et. al. (2014). President Erdoğan: Prospects for a Strong Presidency. Pobrane z: https://bipartisanpolicy.org/wp-content/uploads/2019/03/BPC_President_-Erdogan_Turkey.pdf.

Bichta, T., Kowalska, M., Sokół, W. (2005). System polityczny Rosji. W: W. Sokół, M. Żmigrodzki (red.). Systemy polityczne państw Europy Środkowej i Wschodniej (ss. 385-431). Lublin: Wydawnictwo UMCS.

Bieniek, K. (2013). System partyjny Republiki Turcji w latach 1950-2011. Warszawa: Dom wydawniczy ELIPSA.

Bieniek, K. (2016). Ewolucja pozycji ustrojowej władzy wykonawczej w Republice Turcji. Białostockie Studia Prawnicze, 20(B), 395-405.

Bożyk, S. (2009). Pozycja ustrojowa Rady Państwa w Konstytucji PRL z 22 lipca 1952 r. Miscellanea Historico-Iuridica, VIII, 161-174.

Bryc, A. (2009). Rosja w XXI w. Gracz światowy czy koniec gry? Warszawa: Wydawnictwo Akademickie i Profesjonalne.

Chmaj, M., Żmigrodzki, M. (2001). Wprowadzenie do teorii polityki. Lublin: Wydawnictwo Uniwersytetu Marii Curie Skłodowskiej.

Chmielowska, D., Sobczak, M. (2016). Demokracja po turecku. Studia Europejskie, 4, 205-232.

Chudziak, M., (2017), Reforma ustrojowa w Turcji - prezydent bierze wszystko. Pobrane z: https://www.osw.waw.pl/pl/publikacje/analizy/2017-01-25/reforma-ustrojowa-wturcji-prezydent-bierze-wszystko. 
Chudziak, M. (2018). Turcja: podwójne zwycięstwo Erdoğana. Pobrane z: https://www. osw.waw.pl/pl/publikacje/analizy/2018-06-25/turcja-podwojne-zwyciestwo-erdogana.

Ciapała, J. (1996). Status ustrojowy prezydenta jako głowy państwa. Ruch Prawniczy, Ekonomiczny i Socjologiczny, LVIII(2), 13-28.

Çolak, Ç., Şener, B., Bilgili, M. (2017). Comperative Analysis of the Turkish Presidential System with Government Systems Including Separation of Powers. Kastamonu Üniversity Journal of faculty of Economics and Administrative Sciences, 18(1), 114-127.

Elman, P. (2014). Turkey's Presidential Election: How Should the EU Address a Political System in Flux? Biuletyn PISM, 105(700).

Gülener, S., Miş, N. (2017). Constitutional Framework of Executive Presidency in Turkey. Pobrane z: https://setav.org/en/assets/uploads/2017/04/ExecutivePresidency.pdf.

Kaya, Ö. (2011). On the Way to a New Constitution in Turkey Constitutional History, Political Parties and Civil Platforms. Pobrane z: http://library.fes.de/pdf-files/bueros/ tuerkei/12220.pdf.

Knopek, J. (2016). Europejskie systemy polityczne. Warszawa: Difin.

Kryszeń, G. (2019). System rządów zgromadzenia w konstytucji Turcji z 1921 r. Miscellanea Historico-Iuridica, XVIII(1), 71-90.

Konstytucja Republiki Tureckiej. Pobrane z: http://biblioteka.sejm.gov.pl/wp-content/ uploads/2017/08/Turcja_pol_010717.pdf.

Makovsky, A. (2017). Erdoğan's Proposal for an Empowered Presidency. Pobrane z: https:// www.americanprogress.org/issues/security/reports/2017/03/22/428908/erdogans-proposal-empowered-presidency/.

Marszałek-Kawa, J., Burak, A. (2018). The Political System of the Republic of Turkey. Past and Present. Przegląd Politologiczny, XXIII(3), 95-108.

Matusiak, M. (2015). Wielki Skok. Turcja pod władza Erdoğana. Pobrane z: https://www. osw.waw.pl/sites/default/files/pw_51_pl_wielki-skok_net.pdf.

Osiński, J. (2009). Prezydent Stanów Zjednoczonych Ameryki. W: J. Osiński (red.). Prezydent w państwach współczesnych. Warszawa: Szkoła Główna Handlowa w Warszawie.

Özbudun, E. (2014). The 2014 Presidential Elections in Turkey: A Post-election Analysis. Pobrane z: http://www.iai.it/sites/default/files/gte_pb_18.pdf.

Pogłódek, A., Przywora, B. (2016). Zasady podziału władzy w Turcji. W: S. Grabowska, R. Grabowski (red.). Zasady podziału władzy we Współczesnych Państwach Europejskich (ss. 341-352). Rzeszów: Wydawnictwo Uniwersytetu Rzeszowskiego.

Potulski, J. (2005). Rola i znaczenie tradycji w funkcjonowaniu wspótczesnych instytucji politycznych $w$ Rosji. Toruń: Europejskie Centrum Edukacyjne.

Sarnecki, P. (2013). Ustroje Konstytucyjne Państw Wspótczesnych. Warszawa: Lex a Wolters Kluwer business.

Stembrowicz, J., Szymczak, T. (1966). Głowa państwa w systemie socjalistycznym (naczelne organy typu prezydialnego i prezydent republiki). Ruch Prawniczy, Ekonomiczny i Socjologiczny, 28(1), 1-22. 
Szymanek, J. (2017). Legislatywa i egzekutywa w prezydenckich i półprezydenckich systemach rządów. Przegląd Sejmowy, 1(138), 103-136.

Szymański, A. (2006). System konstytucyjny Turcji. Warszawa: Wydawnictwo Sejmowe, Warszawa.

Szymański, A. (2008). Prezydent w systemie politycznym Republiki Turcji: na tle aktualnej debaty ustrojowej. W: T. Mołdawa, J. Szymanek (red.). Parlament. Prezydent. Rząd. Zagadnienia konstytucyjne na przykładach wybranych państw. Warszawa: Dom Wydawniczy ELPISA.

Turek, M. (2014). System prezydencki w praktyce politycznej USA. W: J. Szymanek (red.). Systemy Rzadów perspektywie porównawczej. Warszawa: Kancelaria Sejmu.

Wasilewski, K. (2017a). Turcja na drodze do systemu prezydenckiego. Biuletyn PISM, 17 (1459).

Wasilewski, K. (2017b). Turcja w procesie przemian: wnioski dla strategii UE. Warszawa: Polski Instytut Spraw Międzynarodowych.

Wasilewski, K. (2017c). Constitutional Referendum in Turkey. Pobrane z: https://pism. pl/publications/Constitutional_Referendum_in_Turkey.

Wódka, J. (2015). (De)europeizacja tureckich partii politycznych: aspekty instytucjonalne i transnarodowe. W: A. Cianciara, A. Burakowski, P. Olszewski, J. Wódka (red.). Europeizacja partii politycznych i grup interesu. W wybranych państwach Partnerstwa Wschodniego i kandydujacych do Unii Europejskiej (ss. 141-182). Warszawa: Instytut Studiów Politycznych PAN.

Yokuş, S. (2018). Elections and tThe Presidential System in Turkey. Is a return to democratisation possible in this new period?. Pobrane $\mathrm{z}$ : https://www.democraticprogress. org/wp-content/uploads/2018/09/4.April2019-SevtapYoku\%C5\%9FAugustAssessment2018-Proof2-WEB.pdf.

Żarnowski J. (2012). Współczesne systemy polityczne. Zarys Problematyki. Warszawa: Uczelnia Łazarskiego. 